\title{
THE CALLING AND WORK OF WELLINGTON MASATIA TAMBWA. A TRADITIONAL HEALER FROM BUNYORE, KENYA
}

\section{Ezekiel Alembi}

In this paper, I will introduce the work of one Kenyan healer, Mr. Wellington Masatia Tambwa. The paper is divided into two parts. The first part discusses the theme of healing and medicine in Africa and gives a short evaluative overview of the works of Edward E. Evans-Pritchard, Huges, John S. Mbiti, K. Thairu and Raimo Harjula. The purpose of this discussion is to show the gap which, I argue, should be filled by scholars interested in this theme in Africa. The second part of this paper discusses the work of Masatia Tambwa. This contributes to fill the aforesaid gap.

Empirical data for this paper comes from a number of people, whom I interviewed in Bunyore. It would be difficult to name all of them here, so I will name only a few: Joseph Osuka, Fronika Ayoti Osuka and John Irili. Discussions with these people offered me a good opportunity to learn about the healer Masatia Tambwa and his background. Much information concerning the medicine man came from discussions with Masatia himself.

\section{AFRICAN HEALING AND MEDICINE IN LITERATURE}

It has already been established that the science of medicine existed in Africa long before the coming of the white people. Traditional doctors were and still are greatly respected by everybody (Thairu 1985: 85). J. S. Mbiti (1969: 166) calls them "friends of the community". This attitude may be explained by the fact that these doctors play an essential role in relieving pain and restoring life and health.

The topic of medicine in Africa has been discussed by many scholars. The discussions, however, have in the most part been general, covering the whole continent (Mbiti 1969: 166-171; Thairu 1985: 
85-98) or entire communities (Evans-Pritchard 1937: 202-250; Kuper \& Hughes \& Velsen 1954).

$\mathrm{K}$. Thairu, for example, presents a long discourse centered on healers and healing in Africa. Without naming the communities in Africa from which he draws his examples, $K$. Thairu argues that this continent had doctors and surgeons even before the advent of modern medicine. He gives examples of how such surgeons treated fractures and wounds and in some cases even performed major operations (Thairu 1985: 86).

According to K. Thairu, doctors in ancient West Uganda delivered complicated births by Caesarian section. Most African communities practiced craniotomy (Thairu 1985: 87) - the opening of the skull to relieve pressure causing headaches with brain tumors, etc.

Evidently, Africans were quite advanced in medicine. In a general discussion that draws examples from the whole of Africa, John S. Mbiti (1969:166-171) discusses the status and role of medicine-men in Africa. In describing the calling of the medicine-man in Africa, John S. Mbiti (1969: 167) notes that "There are medicine-men who believe that spirits or the living-dead have called them in dreams, visions or in waking to become medicine-men." This is an overgeneralized observation about the calling of medicine-men in Africa. Unfortunately, it is not clear what medicine-men and what community in Africa is John S. Mbiti referring to. Secondly, not all medicine-men receive their calling in a similar way and under similar circumstances. Discussion with the healer Masatia from Bunyore revealed that there are specific circumstances under which people are initiated into healing.

John S. Mbiti proceeds to discuss the duties of a medicine-man in Africa. On examples from the Ndebele in South Africa, John S. Mbiti (1969: 168) notes that the medicine-man supplies medicated pegs for the gates of a new homestead, combats witchcraft and magic by preventing their activation and sometimes sending them back to their authors, and strikes the grave of a dead person saying "N.N., wake up! Go and fight”. Kuper \& Hughes \& Velsen (1954: 108) observe that the Ndebele believe that the spirit of the dead person wakes up and goes in the form of a small animal to the home of the witch who killed him. The animal waits there until one of the mem- 
bers of the witch's family sees and kills it. Then members of that family begin to die. If the family of the witch admits guilt then its members pay with cattle to the family of the dead man and the revenge curse is lifted, or a powerful medicine-man is called to lift and put an end to it.

According to E. E. Evans-Pritchard (1937: 251-257), "Among the Azande the medicine-man cures the sick and warns of impending danger. It is he who removes failure from hunting and from farming. He can harm or protect, kill or cure." He attacks witchcraft and magic with his medicines and keeps a stock for this and other purposes. Nobles are said to patronize medicine-men because their magic is good magic. It causes no one injury and protects many from harm. Everybody agrees that the medicine-man is harmless, and everyone praises his medicine; even if the medicine-men fight with each other, they do not harm other people. Princes also patronize and protect medicine-men, especially in order to get protection against witchcraft and political conspiracy. Every medicine-man is "a professional indicator of witchcraft."

In the general discussion above, scholars John S. Mbiti, H. Kuper, A. J. B. Hughes, J. van Velsen and E. E. Evans-Pritchard do not give the reader important facts related to the topic. For example, what is the composition of drugs administered to the patients or installed at strategic points on gates or in homesteads? How are the drugs collected and processed? Are they administered at night or during the day, and why? Who are the specific medicine-men discussed? What do they specialize in, in healing? As it is, the descriptions offered above are too general and simplistic for such a complicated and even controversial subject.

R. Harjula (1980) presents a treatment that is specific in the sense that it is from a specific medicine-man, Mirau, from a specific community, Meru, in a specific country, Tanzania. The discussion on Mirau is divided into different subjects, including an introduction which outlines the purpose of the study, description of the research process and a brief biography of Mirau. The second part analyses collection methods and preparation of remedies, while the third concentrates on diagnosis and choice of remedies. The fourth is on miscellaneous illnesses, while the fifth forms the conclusion and suggestions for future studies. 
Of all the studies on African healers, I recommend R. Harjula's. We learn about the character of the healer and the specific methods of treatment. It is on the basis of such studies that generalizations can then be made. In the case of most African healers, their origin, family and kinship ties and traditional heritage, including folklore and folk belief, are essential in determining their practice.

\section{MASATIA, THE MAN FROM BUNYORE}

The healer Wellington Masatia Tambwa was born on June 6, 1933, in Ebwiranyi Ebunabule village in the present Vihiga District of Western Province of Kenya. His father, also a medicine-man, was Tambwa Mang'ula and his mother was Salome Amisa. Masatia inherited the powers of healing from his father, who in turn had inherited such powers from his father, Mang'ula.

Masatia had two brothers and three sisters. The brothers, all deceased now, were Makhuka Tambwa and Kweya Tambwa. The names of the sisters are: Afuya, Otwelo, and Alembi. The youngest of the sisters, Otwelo died in 1953.

Masatia Tambwa grew up as a normal child, doing what other children of his age and time did. He attended school at Ebuyalu Day, Ebusakami Primary and Esiandumba Intermediate. He left school when he was in grade two at Esiandumba, because his parents could not afford to pay the fees.

Masatia went to Ziwani Sisal Etate, where he worked for many years, first as a sisal cutter and later, after being promoted, as an overseer. Tired of life at the sisal estate and looking for new challenges and adventures, young Masatia moved to Nairobi where he was lucky to get a job as a clerk at the Medical Training Center at Kenyatta Hospital. This was and still is the largest Medical school in Kenya, where he worked until retirement.

The healer Wellington Masatia Tambwa openly boasts that girls loved him and he in turn loved girls. However, in August 1956, he decided to make a choice and settle down as a family man. This year, he married his first wife, Rina. Eleven years later, he married Susan, a colleague at Kenyatta Hospital in Nairobi. 
Masatia has nineteen children with his two wives. With Rina he has nine children, three of whom - Okelo, Moti ad Naomi - have died, but Tiko, Odongo, Atulo, Otwelo, Josephine and Ayitso are still living. With Susan he had ten children, three of whom - Tom, Tambwa and Atulo - have died, while seven are still alive: Daniel, John, Obadiah, Angeline, Luciana Dorcas and Salome.

\section{MASATIA THE HEALER}

According to both Masatia himself and my informants, his becoming a healer took time and supervision from his father, as is typical for many folk healers. It all started one fine morning in 1943 when Masatia was called by his father. He, being an obedient child, responded promptly. "I want you to join me in the bush to visit our ancestors," said the ageing Tambwa Mang'ula. This came as a surprise to Masatia because the old man had not invited his other two sons, both older than Masatia, to join him. Masatia was lost for words but obediently followed his father. At this time, he did not even understand what "visit our ancestors" meant.

"Do you see this plant!" explained the old man when they had reached the bush. "It is used to treat people, who have been attacked by evil spirits," he said. They moved on, young Masatia uncomfortable but afraid to admit it. His father was a very harsh man and Masatia feared what would happen to him if he dared to display fear or said anything that would annoy the old man.

"This plant here," the old man continued after they had walked some distance, "It is a bad plant. Witches use it to kill. Do not ever touch it!”

They walked on. "That plant", the old man was pointing to a bush about three feet away, "that one is good for immunity. When you lick its ashes, nobody can succeed in bewitching you."

The sun was nearly in the center of the sky when the old man and son started to walk back home. For the next six years, Masatia went to "visit our ancestors" in the bush. During this time, he learnt the names and uses of many medicinal plants. He learnt of the plants and bushes that could be used for treating people, when at- 


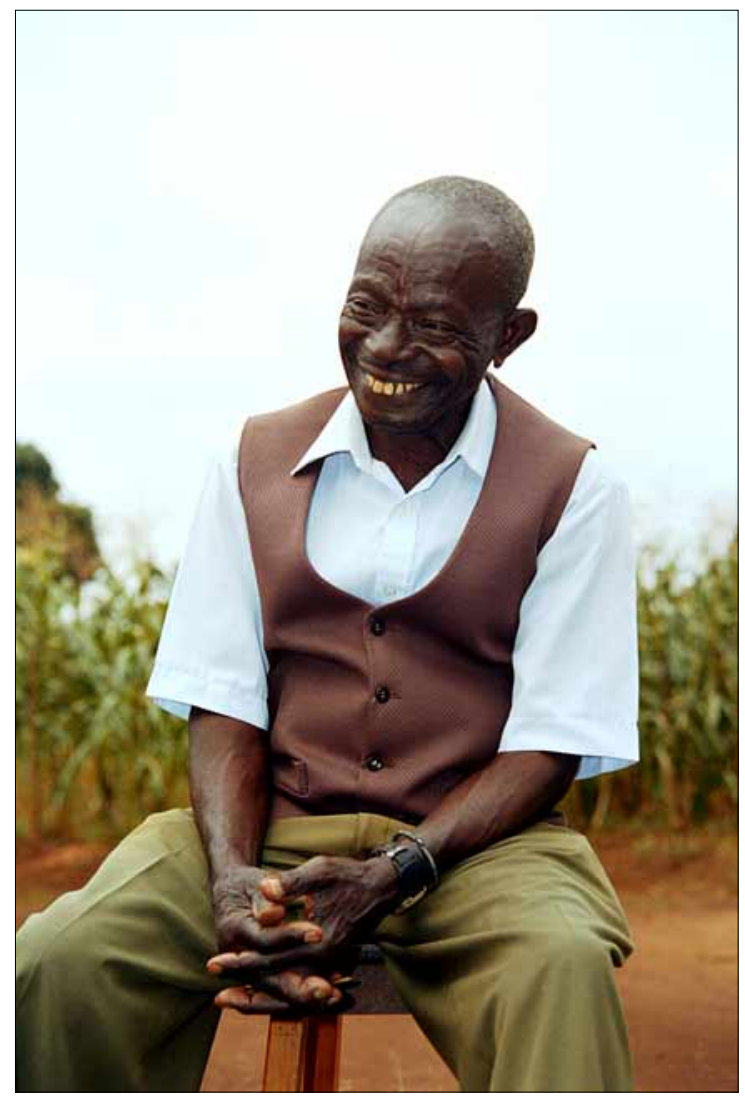

Photo 1. Wellington Masatia Tambwa in his home. Photo by Andres Kuperjanov, 2000.

tacked by evil spirits and jinns, people who had been bewitched and plants that could restore love between fighting couples. He also learnt about the plants and bushes that could be used to make people immune to witchcraft. The old man Tambwa also taught his son about the plants that could be used to make witchcraft bounce back to its author.

When he reached the age of sixteen, Masatia started to frequently visit the ancestors in the bush alone. On such occasions, he would collect the plants and bushes on his father's request. Masatia was 
slowly being transformed into a medicine-man. His two brothers, Makhuka and Kweya became very jealous of him. By 1970, the hostile feelings of Makhuka and Kweya had grown to dangerous proportions. The ageing Tambwa Mang'ula noticed that and was quite disturbed. So, he planned to test his three sons to put a stop to the ill feelings that had now fully developed between the two and Masatia.

\section{THE TRIAL}

For a folklorist, the solution to the complicated rivalry between bothers, is both interesting and educative. It took place on an evening in 1970 when Tambwa and his three sons met.

"You two," he started, pointing at his two sons, Makhuka and Kweya. "You keep bad feelings about your brother Masatia because I have shown him some of our ancestors' plants and bushes." He paused, looked at the duo and continued, "He is close to me. You two run all over and fear to come and talk to me." There was a long silence.

"Since you have now, so belatedly, shown interest in our ancestors' plants and bushes, I will show them to you. Come tomorrow, all of you, and I will take you to visit our ancestors in the bush. You must be here before the sun comes up."

Early the following morning, before the sun rose, all the three brothers had assembled in their father's house. Soon they were out and on their way to the bush. The old man led the way. There was a total silence as the father and sons walked.

"There's our ancestor's home," the old man said, pointing to the bush about ten meters away.

They entered the bush and walked on deep into it. Deeper and deeper into the bush they walked. Then the old man announced, "We have arrived." Makhuka and Kweya looked exhausted. Masatia was still strong. He had been here many times before.

Looking at a bush about five feet away, the old man told his eldest son, Makhuka, "Go and fetch me some leaves from that bush." 
Makhuka walked majestically towards the bush. When he was about two feet away, he stopped, wailed loudly and ran back very fast crying, "Snake! Huge snake!" The brothers looked on, surprised. They could not see the snake that Makhuka was shouting about. "Come back!" Tambwa shouted to Makhuka, who had by now covered some distance on the way out of the bush. "Come back, you fool!" Tambwa shouted loudly. Makhuka stopped and started walking back. He was now shaking and sweating.

"Go and get me those leaves!" Tambwa commanded. Makhuka shook his head, a sign that he would not go back to the "snake".

It was now Kweya's turn. Kweya strongly walked towards the bush, which he could see clearly. He could not understand what his brother, Makhuka, was shouting about. There was no snake.

When he was a short distance from the bush, he stopped suddenly, turned back quickly and started wailing at the top of his voice as he ran away.

"Stop and get me the leaves, you fool!" shouted the old man. But Kweya would not listen. "Get me the leaves!" The old man shouted time and again. Kweya stopped, panting. "Come back here," ordered the old man. Kweya came back trembling.

Masatia walked towards the bush. When he was close to it, the bush turned into a huge snake with several mouths. Out of the mouths, tongues of fire dangerously darted in and out. He moved on, carefully observing the movement of the snake's heads. Now he was one foot away. Determined he moved on.

"Wood mama, get me those leaves," said the old man. Masatia stopped suddenly. He had actually reached the bush and there was no snake. He plucked the leaves and walked back with them. The old man took the leaves from the son, gently spat on them, and gave them back to the son saying, "These leaves, from today on, belong to you."

Makhuka and Kweya walked away in protest. They knew what the father's words meant. He had blessed Masatia to carry on the family's healing tradition. 


\section{THE SEAL}

The following cases in the Masatia family have been explained and interpreted against the background of prophetic dreams and their importance, as well as traditional intratribal relations. We see that such visions and messages have a role in dictating the course of events.

In 1971, the aged medicine-man Tambwa Mang'ula passed away to join the ancestors. At this time, Masatia was away on duty at the Medical Training Center in Nairobi. On the night after the day the old healer died, he appeared to his son Masatia in a dream with the following message: "Don't cry, my son. All is well. I have prepared a smooth transition."

Determined to bury their father without Masatia's knowledge, Makhuka and Kweya refused to inform their brother about the death. Fortunately, Alembi, Masatia's sister, who was also in Nairobi at that time, heard the news and informed her brother about it.

Masatia arrived home, luckily, before the burial of his father. The same afternoon when he arrived, his father sent word in a dream that he should be given Omukasa, the family chain. The dream was sent to one Amukhale. The deceased medicine-man told Amukhale that he had Omukasa on the wrist of his left hand. Amukhale woke up from the afternoon nap and ran to the funeral place. He got Omukasa and handed it to Masatia, who was sitting next to the body of his late father.

By handing over Omukasa (a symbol of power, authority and, in this situation, the family healing tradition), the dead healer was saying that although youngest in the family, Masatia was given the authority to lead the Tambwa family. He was also given the authority to lead the Abanabule clan in meetings, etc. The family blood of healing would flow through Masatia.

\section{WHAT DOES MASATIA TREAT?}

This healer specializes in treating: 
1. Victims of witchcraft. Masatia, however, insists that the victim must be innocent. This way, the drug works fast and efficiently. If the victim is guilty of some misdeed that resulted in his/her being bewitched, then it is possible that this victim may get hurt in the treatment. It is as if, in this case, Masatia is calling on people to live in peace, saying that it is difficult to hurt a peaceful person.

In this society, witches are greatly feared. They kill, drive eople mad or even become stupid. The main cause of one becoming the target of witches is jealousy.

2. Making people immune against theworks of witches, robbers. When one keeps a particular kind of drug at home, robbers will find it difficult to break in. In my discussion with the healer, he emphasized that if robbers approach a home where this drug is kept, the home may turn into a water body (sea, lake, river, etc.) or even an animal (lion, snake, etc.) or a mountain in the robbers' eyes.

3. People with marital problems. Masatia can supply a drug that can restore love and happiness at home.

4. People who find it difficult to get lovers. He says that he can supply love potions that can help such people enjoy healthy love relationships.

5. People who have been attacked by evil spirits and jinns. Spirits and jinns are known to cause a lot of suffering in Bunyore. They strangle people, beat them up, shout around homes and cause discomfort, eat all the food before the owners come to the table, etc. Masatia is therefore important as he can help such people.

\section{DIAGNOSING PROCESS}

Masatia gives his patients time to explain what they are suffering from. From the description, he gathers knowledge about what the problem is likely to be.

This healer is a herbalist, using only medicine from plants: leaves, roots and the bark of trees. He collects them, as stated earlier, from the bush near his village. 
There are various ways of preparing drugs:

1. Pounding leaves, roots, bark or a mixture of these. The pounded drug is soaked in water and the patient is made to drink the mixture.

2. The leaves, roots and bark are dried and burnt into ashes. The ashes are then given to the patients to lick.

3. The patient is given a root, leaves, bark or a mixture to chew.

4. This healer could not disclose to me the names of the plants and bushes he uses in treating his patients. He insisted that this is a secret to be revealed only to the person in the family to whom he will pass this knowledge.

\section{CONCLUSION}

From this discussion, it becomes clear that the calling and training of a healer are important if we are to understand the work a healer does. In Masatia'a case we saw how closely explanations for common diseases and his field of action and healing methods are related and limited to what he has learned from his father. A strong system of beliefs is indicated by, for example, the fact that plant names can only be revealed to a descendant, the next medicineman-to-be.

The data received from Masatia and other interviewees explains why I have rejected the generalized discussions on this subject by E. E. Evans-Pritchard (1937), H. Kuper, A. J. B. Hughes, J. van Velsen, John S. Mbiti (1969), and K. Thairu (1985). It also emerges from this discussion that no single healer can handle all types of illnesses. Discussing the work of individual healers is therefore important, as this will offer the readers interested in this subject an opportunity to understand which specialization a healer has. This can then provide an opportunity to generalize on healers and healing in Africa in the future. For this reason, I prefer the work of R. Harjula (1985) - it lays a good foundation for this kind of thinking and work. I hope more scholars will take up the challenge to study the works of individual healers in Africa. 


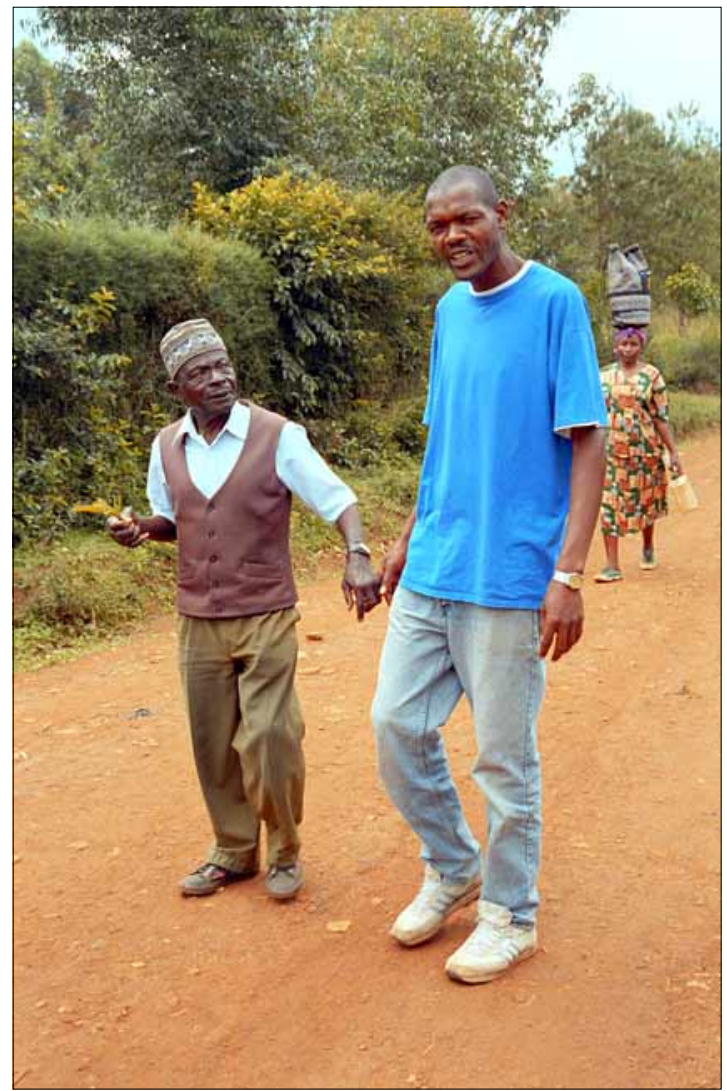

Photo 2. Wellington Masatia walking on the village street with a man from a neighbouring village. Photo by Andres Kuperjanov, 2000.

\section{References}

Harjula, Raimo 1980. Mirau and his practice. A Study of the Ethnomedicinal Reportoire of a Tanzanian Herbalist. London: Tri-Med.

Thairu, Kihumbu 1985. Utamaduni wa kiafrika. [The African Civilization] Nairobi.

Mbiti, John S. 1969. African religions and philosophy. London: Heinemann.

Evans-Prichard, Edward E. 1937. Witchcraft, Oracles and Magic among the Azande. Oxford: Faber and Faber.

Kuper, Hilda \& Hughes, A. J. B. \& van Velsen, J. 1954. The Shona and Ndebele of Southern Rhodesia. London: International African Institute. 